ABDIMAS: Jurnal Pengabdian Masyarakat Universitas Merdeka Malang
Vol.7(1) February 2022, 73-83
L-ISSN: 2721-138X e-ISSN: 2548-7159
Uttp://jurnal.unmer.ac.id/index.php/jpkm

\title{
Santri trained troops: Making new normal kits and training for the COVID-19 task force
}

\section{Trained troops santri: Pembuatan new normal kit dan pelatihan satgas}

\section{COVID-19}

\author{
Meta Maulida Damayanti ${ }^{1}$, Yuniarti Yuniarti ${ }^{2}$, Meike Rachmawati ${ }^{1}$, Mia Kusmiati ${ }^{3}$ \\ ${ }^{7}$ Department of Pathology Anatomy, ${ }^{2}$ Department of Anatomy, ${ }^{3}$ Department of Medical Education, Bioethics, and Humanity, \\ Faculty of Medicine, Universitas Islam Bandung \\ Jl. Taman Sari No. 20, Bandung, 40116, Indonesia
}

\begin{abstract}
ARTICLE INFO:
Received: 2020-12-21

Revised: 2021-04-04

Accepted: 2021-08-17

Keywords:

COVID-19, New normal kit, Trained troops santri

\section{ABSTRACT}

Since the COVID-19 pandemic first emerged in December 2019 and was confirmed in Indonesia in March 2020, the Indonesian government has imposed a strict lockdown. The number of confirmed cases is increasing all the time. Efforts to prevent transmission must be carried out immediately, including improving health protocols. The activity aims to create trained troops Santri, by providing insight into COVID-19 which consists of training to implement health protocols and soft skills for making new normal kits, namely hand sanitizers and cloth masks. The activities were carried out at the Manarul Huda Islamic Boarding School, Bandung to 31 Santri. The new normal kit manufacturing training is accompanied by an expert. The training of Santri produces cadres with a level of knowledge about COVID-19 most highly with a fair category (51,61\%). Based on the percentage of the group, age $>17$ years, male gender, and education level graduated from school have a higher level of good knowledge than other groups. This service activity produces trained troops Santri equipped with knowledge about COVID-19 particularly good health protocols, has soft skills to make hand sanitizers and cloth masks. Towards they can produce a new normal kit and create a COVID-free Islamic boarding school area.

(c) 2022 Abdimas: Jurnal Pengabdian Masyarakat Universitas Merdeka Malang This is an open access article distributed under the CC BY-SA 4.0 license (https://creativecommons.org/licenses/by-sa/4.0/)
\end{abstract}

How to cite: Damayanti, M. M., Yuniarti, Y., Rachmawati, M., \& Kusmiati, M. (2022). Santri trained troops: Making new normal kits and training for the COVID-19 task force. Abdimas: Jurnal Pengabdian Masyarakat Universitas Merdeka Malang, 7(1), 73-83. https://doi.org/10.26905/abdimas.v7i1.6020

\section{PENDAHULUAN}

Pada Bulan Desember 2019, Virus Korona yang tidak teridentifikasi sebelumnya, yang saat ini dikenal sebagai Novel Corona Virus 2019 (COVID-19), muncul pertama kali di Wuhan, sebuah kota di Provinsi Hubei China, dan menyebar ke seluruh dunia, sehingga menciptakan krisis pandemi menurut World Health Organization (WHO) yang menyerang di semua Negara termasuk Indonesia (Parasher, 2021; Shirani, 2020; Velavan \& Meyer, 2020). COVID-19 telah membuat dampak perubahan besar pada 
ABDIMAS: Jurnal Pengabdian Masyarakat Universitas Merdeka Malang

Volume 7, No 1, February 2022: 73-83

populasi manusia setelah Coronavirus sindrom pernapasan akut berat (SARS-CoV) pada tahun 2003 dan Coronavirus sindrom pernapasan Timur Tengah (MERS-CoV) pada tahun 2012 (Shereen et al., 2020). COVID-19 adalah jenis virus yang menyebabkan pneumonia akibat sindrom pernafasan akut Coronavirus 2 (SARS-CoV-2) (Dharmaraj et al., 2021). Pada 6 Maret 2020, Pemerintah Indonesia mengumumkan kasus pertama COVID-19 di Indonesia, dan memberlakukan lockdown. Besarnya kecepatan dan ketidakpastian pandemi telah memengaruhi semua sistem dan berdampak besar pada hampir semua aspek di kehidupan masyarakat serta memicu inovasi di banyak bidang, termasuk bidang kesehatan, salah satunya yaitu kesehatan perilaku (Gibbons et al., 2021; Pinals et al., 2020).

WHO mengeluarkan pedoman untuk membantu mengurangi penyebaran virus, seperti aturan memakai masker, kebersihan tangan, jarak sosial, dan menonaktifkan beberapa kegiatan publik. Pengendalian wabah untuk mengurangi transmisi perlu dilakukan secara menyeluruh. Populasi yang berisiko harus mendapat perhatian serius (Tosepu, 2020). Pesantren merupakan suatu populasi lembaga pendidikan keagamaan yang tumbuh dan berkembang dari masyarakat yang berperan penting dalam pengembangan sumber daya manusia. Populasi pesantren sangat beragam, pentingnya pemahaman tentang kesehatan khususnya dalam penyebaran COVID-19 harus mendapatkan perhatian khusus. Pimpinan, pengurus, dan santri diharapkan tidak saja mahir dalam aspek pembangunan akhlak dan intelektual spiritual, namun dapat pula menjadi motivator dan inovator dalam pembangunan kesehatan, serta menjadi teladan dalam berperilaku hidup bersih dan sehat bagi masyarakat sekitarnya (Sebong et al., 2021; Khoiroh \& Fachrunisa, 2020; Syam et al., 2018). Upaya untuk meningkatkan kesehatan khususnya dalam rangka memutus transmisi COVID-19 adalah dengan penerapan protokol kesehatan yang baik, dimulai dari pengetahuan santri terhadap kondisi pandemi, transmisi serta pencegahannya, mengingat pesantren terdiri dari ratusan orang yang tinggal bersama, dan tidak jarang menerima tamu dari luar. Pesantren Manarul Huda merupakan salah satu pesantren di Bandung, yang terletak di Citra Green Dago, Kota Bandung, berbatasan dengan Kabupaten Bandung Barat (Gambar 1). Pesantren Manarul Huda berjarak $5.4 \mathrm{~km}$ dari lokasi institusi tim pengabdi, dan dapat ditempuh dalam waktu 12 menit perjalanan normal menggunakan kendaraan bermotor sehingga memudahkan koordinasi.

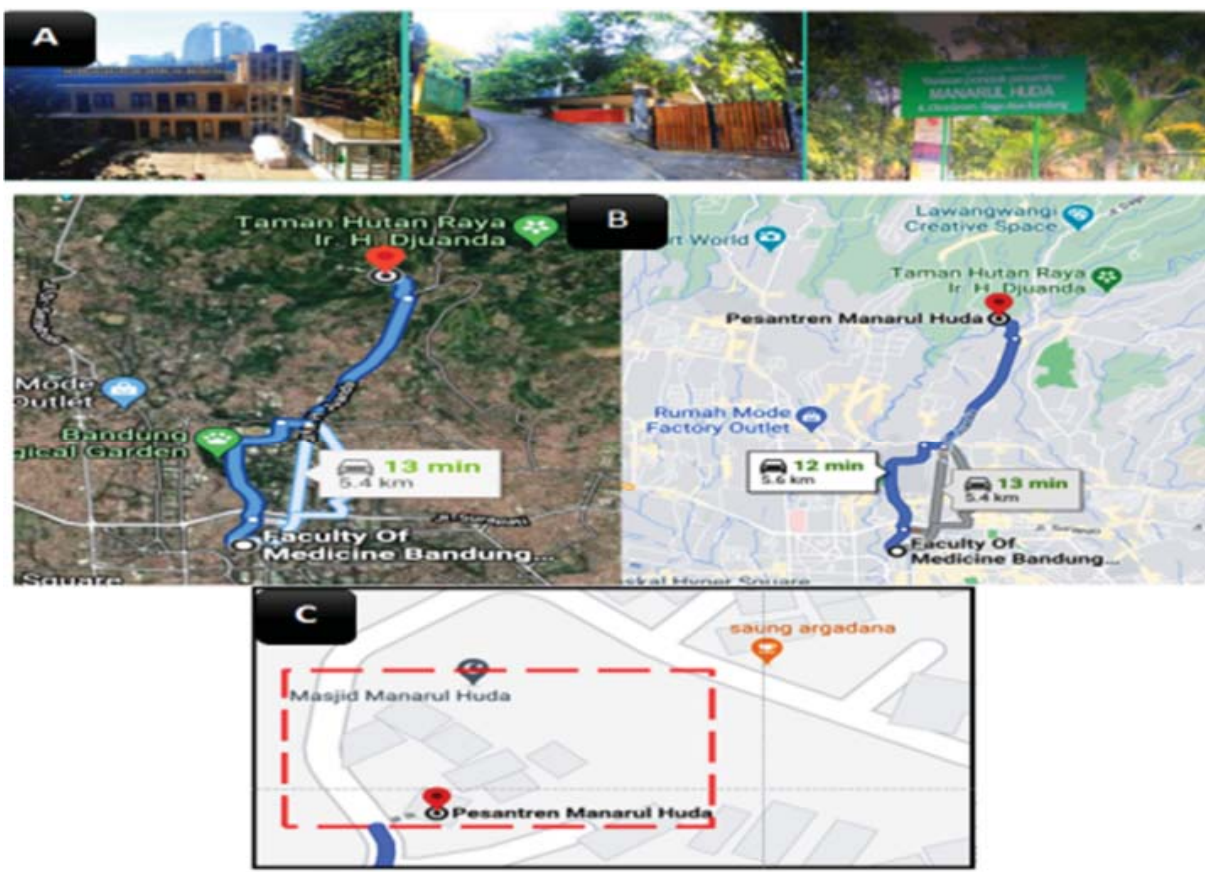

Gambar 1. Pesantren Manarul Huda, jarak pesantren dari lokasi tim pengabdi, lokasi bangunan pesantren 


\section{Santri trained troops: Making new normal kits and training for the COVID-19 task force}

Meta Maulida Damayanti, Yuniarti Yuniarti, Meike Rachmawati, Mia Kusmiati

Berdasarkan analisis situasi, lokasi pengabdian ini belum melakukan penerapan protokol kesehatan secara komprehensif dan untuk meningkatkan protokol kesehatan dibutuhkan tim khusus yang terlatih serta dibutuhkan fasilitas penunjang lain dalam jumlah banyak yaitu new normal kit berupa handsanitizer dan masker (Tabel 1). Penyediaan fasilitas seperti handsanitizer, dan pemasangan posteryang merinci langkah-langkah cuci tangan sangat penting di setiap fasilitas cuci tangan. Saat ini, penggunaan masker merupakan bagian dari kebutuhan dasar sebagai tindakan pencegahan dan pengendalian yang dapat membatasi penyebaran COVID-19. Selain penggunaan masker anjuran mencuci tangan merupakan himbauan yang harus dilaksanakan. Mencuci tangan dilakukan dengan menggunakan sabun di bawah alir mengalir, apabila tidak ditemukan air atau dalam perjalanan maka dianjurkan penggunaan handsanitizer. WHO merekomendasikan handsanitizer berbasis alkohol untuk kebersihan tangan, yang terutama terbuat dari etanol, isopropil alkohol, hidrogen peroksida dalam kombinasi yang bervariasi. Penggunaan handsanitizer dan masker kain dalam jumlah banyak membutuhkan biaya yang tidak sedikit, sehingga pengadaan new normal kit secara mandiri diharapkan menghasilkan kualitas yang terjamin dan juga efisiensi (Sebong et al., 2021; Gold et al., 2020; Sufiyanto et al., 2020; Yusuf, 2020).

Tabel 1. Permasalahan mitra berdasarkan analisis situasi

\begin{tabular}{|c|c|c|}
\hline Komponen & $\begin{array}{l}\text { Rincian Permasala- } \\
\text { han }\end{array}$ & Solusi \\
\hline \multirow[t]{6}{*}{ Permasalahan SDM } & $\begin{array}{l}\text { Kurangnya penge- } \\
\text { tahuan mengenai } \\
\text { COVID-19 khususnya } \\
\text { protokol kesehatan }\end{array}$ & $\begin{array}{l}\text { Dilakukan pelatihan trained troops santri. } \\
\text { Melakukan seleksi dan pelatihan intensif trained troops santri, serta pen- } \\
\text { dampingan baik melalui demonstrasi maupun simulasi. Kegiatan ini dibagi } \\
3 \text { tahapan: }\end{array}$ \\
\hline & & $\begin{array}{l}\text { 1. Tahap pertama pemilihan trained troops santri berdasarkan usia dan } \\
\text { tingkat pendidikan serta memberi pernyataan kesanggupan menjadi } \\
\text { relawan dan mengikuti rangkaian pelatihan. }\end{array}$ \\
\hline & & $\begin{array}{l}\text { 2. Tahap kedua sosialisasi, pelatihan, dan focus group discussion (FGD). } \\
\text { Santri akan diberikan materi berupa pengetahuan mengenai protokol } \\
\text { kesehatan terutama berkaitan dengan pencegahan COVID-19 yang dis- } \\
\text { ampaikan oleh tim dengan pemaparan presentasi interaktif. }\end{array}$ \\
\hline & & $\begin{array}{l}\text { 3. Tahap ketiga demonstrasi mengenai tugas trained troops santri serta } \\
\text { pelantikan trained troops santri. }\end{array}$ \\
\hline & $\begin{array}{l}\text { Kebutuhan softskill } \\
\text { keterampilan mem- } \\
\text { buat masker }\end{array}$ & $\begin{array}{l}\text { Dilakukan pelatihan keterampilan membuat masker akan dilakukan dengan } \\
\text { bimbingan produsen masker kain melalui } 2 \text { tahap, yaitu demonstrasi pem- } \\
\text { buatan masker serta hands on pembuatan masker. }\end{array}$ \\
\hline & $\begin{array}{l}\text { Kebutuhan keter- } \\
\text { ampilan membuat } \\
\text { handsanitizer }\end{array}$ & $\begin{array}{l}\text { Dilakukan pelatihan keterampilan membuat handsanitizer dilakukan dengan } \\
\text { mendatangkan ahli farmasi yang dilakukan melalui } 2 \text { tahap, yaitu demon- } \\
\text { strasi pembuatan masker serta hands on pembuatan handsanitizer. }\end{array}$ \\
\hline
\end{tabular}

Kegiatan ini bertujuan untuk menghasilkan kader Santri yang terlatih sebagai petugas pelaksana protokol kesehatan di lingkungan Pesantren serta memiliki kemampuan untuk memproduksi handsanitizer dan masker kain secara mandiri.

\section{METODE}

Program kemitraan masyarakat ini diadakan di Pesantren Manarul Huda, Dago, Bandung, Jawa Barat. Kegiatan program kemitraan masyarakat ini terdiri dari beberapa tahapan, yaitu pelatihan trained troops santri, pelatihan pembuatan handsanitizer, dan pelatihan pembuatan masker kain. Kondisi kelompok mitra yang akan dibina pada kegiatan pengabdian ini terdiri dari 221 orang pemondok yaitu 12 orang pengurus dan 209 orang santri. Santri ikhwan sebanyak 116 orang dan santri akhwat sebanyak 
ABDIMAS: Jurnal Pengabdian Masyarakat Universitas Merdeka Malang

Volume 7, No 1, February 2022: 73-83

93 orang. Dari total 209 orang santri dibentuk trained troops santri sebanyak 31 orang, yaitu 21 orang akhwat dan 10 orang ikhwan. Kegiatan pengabdian ini dilakukan pada Maret 2021 (Tabel 2). Kegiatan pengabdian dilaksanakan oleh tim pengabdi yang terdiri dari 4 orang dosen, 2 orang mahasiswa, 2 orang tenaga ahli dalam bidang pembuatan handsanitizer dan masker kain, serta 2 orang pembantu lapangan.

Tabel 2. Jadwal kegiatan PKM

\begin{tabular}{lll}
\hline \multicolumn{1}{c}{ Kegiatan } & \multicolumn{1}{c}{ Rincian dan Metode Kegiatan } & $\begin{array}{c}\text { Penang } \\
\text { Jawab }\end{array}$ \\
\hline Sosialisasi kegiatan & $\begin{array}{l}\text { Sosialisasi rangkaian kegiatan kepada pengurus dan } \\
\text { santri }\end{array}$ & Tim \\
$\begin{array}{l}\text { Pemaparan materi mengenai } \\
\text { pengetahuan tentang protokol } \\
\text { kesehatan }\end{array}$ & $\begin{array}{l}\text { Melakukan sosialisasi dan penyuluhan mengenai } \\
\text { protokol kesehatan }\end{array}$ & Tim \\
Pelatihan trained troops santri & $\begin{array}{l}\text { Sosialisasi dan eleksi trained troops santri yang ber- } \\
\text { jumlah 30 orang Pelatihan dan FGD }\end{array}$ & Tim \\
$\begin{array}{ll}\text { Pelatihan keterampilan membuat } \\
\text { masker }\end{array}$ & $\begin{array}{l}\text { Sosialisasi kegiatan dan hands on pembuatan } \\
\text { masker }\end{array}$ & Tim dan Produsen \\
Pelatihan pembuatan handsanitizer & $\begin{array}{l}\text { Sosialisai kegiatan dan hands on pembuatan hand- } \\
\text { sanitizer }\end{array}$ & Tim dan Apoteker \\
Pelantikan dan penutupan & Pelantikan peserta dan penutupan kegiatan & Tim \\
\hline
\end{tabular}

\section{Tahap pelatihan trained troops santri}

Pelatihan trained troops santri adalah pelatihan untuk menciptakan kader petugas pelaksana berjalannya protokol kesehatan yang baik di pesantren. Pemberian materi interaktif mengenai COVID19 yang terdiri dari pengetahuan mengenai penyebab, penyebaran, serta pencegahan COVID-19, dilanjutkan oleh forum group discussion dan diakhiri dengan pengisian kuesioner tingkat pengetahuan santri mengenai COVID-19.

Kuesioner pengetahuan COVID-19 dikembangkan oleh tim pengabdi. Kuesioner memiliki 30 pertanyaan. Jawaban yang benar diberi 1 poin dan jawaban yang salah/tidak diketahui diberi 0 poin. Skor total berkisar antara 0 hingga 30, dengan skor yang lebih tinggi menunjukkan pengetahuan COVID-19 yang lebih baik. Kuesioner telah melalui tahap uji validasi dan reliabilitas. Sebelum pengisian kuesioner, dijelaskan mengenai tujuan dan tata cara pengisiannya. Tingkat pengetahuan santri mengenai COVID19 diklasifikasikan dengan penilaian berupa kategori baik ( $\geq 75 \%)$, cukup $(55-75 \%)$, dan kurang $(<55 \%)$.

\section{Tahap pelatihan pembuatan handsanitizer}

Pembuatan handsanitizer dilakukan di bawah pengawasan tenaga ahli yaitu seorang apoteker. Handsanitizer dibuat dengan memenuhi formula pembuatan yang sudah terstandar. Pelatihan ini diawali dengan demonstrasi kemudian melakukan praktik langsung oleh para santri didampingi oleh tim pengabdi.

Bahan yang dibutuhkan adalah Etanol 96\%, Hidrogen peroksida 3\%, Gliserol 98\%, dan air matang steril. Alat yang dibutuhkan adalah botol kaca/plastik $10 \mathrm{~L}$, panci air stainless besar, pengaduk kayu ukuran besar, tabung ukur $1 \mathrm{~L}$, tabung ukur $500 \mathrm{ml}$, corong plastik, dispenser handsanitizer ukuran 500ml, dan termometer air (Gambar 2). 


\section{Tahap pelatihan pembuatan masker kain}

Pembuatan masker kain dilakukan oleh ikatan ibu produsen masker kain. Pelatihan ini diawali dengan demonstrasi dan dilanjutkan dengan praktik langsung oleh para santri. Pada kesempatan ini setiap santri mampu menghasilkan 1 masker kain.

Bahan yang dibutuhkan adalah kain masker luar, kain masker dalam, benang jahit, jarum jahit, karet tali masker, kertas pola, dan jarum pentul. Alat yang dibutuhkan adalah gunting, meteran, dan pensil kain (Gambar 3).
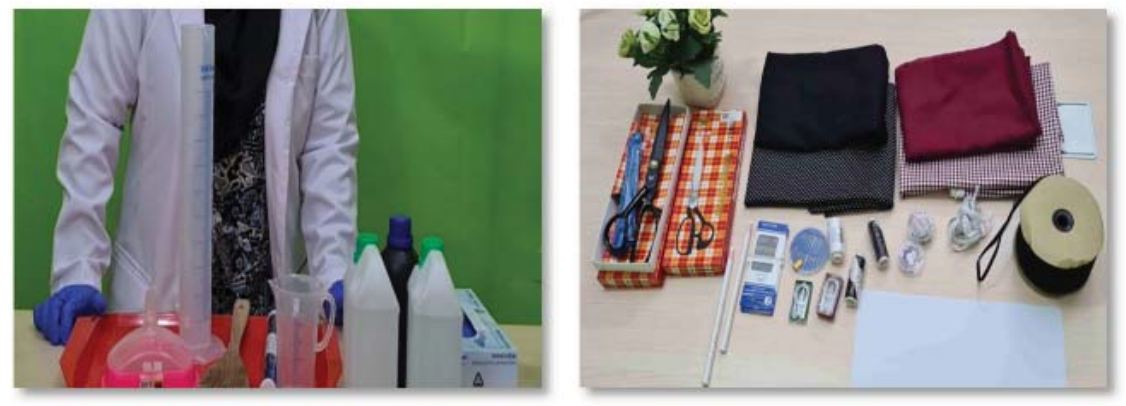

Gambar 2. Bahan dan alat pembuatan handsanitizer

Gambar 3. Bahan dan alat pembuatan masker kain

\section{HASIL DAN PEMBAHASAN}

Kegiatan pengabdian dilaksanakan di Pesantren Manarul Huda Bandung, diikuti oleh 31 trained troops santri, dengan usia paling paling banyak pada rentang $>17$ tahun $(58,06 \%)$, dengan jenis kelamin terbanyak perempuan $(67,71 \%)$, dan jenjang pendidikan terbanyak jenjang aliyah (70,97\%) (Tabel 3).

Tabel 3. Karakteristik trained troops santri

\begin{tabular}{lr}
\hline \multicolumn{1}{c}{ Karakteristik } & $\mathbf{n = 3 1}$ \\
\hline Usia & \\
$\leq 17$ Tahun & $13(41,94 \%)$ \\
$>17$ Tahun & $18(58,06 \%)$ \\
\hline Jenis Kelamin & \\
Laki-laki & $10(32,29 \%)$ \\
Perempuan & $21(67,71 \%)$ \\
\hline Pendidikan & $2(6,45 \%)$ \\
Tsanawiyah & $22(70,97 \%)$ \\
Aliyah & $7(22,58 \%)$ \\
\hline
\end{tabular}

\section{Pelatihan trained troops santri}

Kegiatan pelatihan dilaksanakan di kelas besar pondok Pesantren Manarul Huda dengan ventilasi dan sirkulasi udara yang baik. Seluruh tim dan santri mengikuti kegiatan ini dengan menggunakan protokol kesehatan yang baik. Metode dalam pelatihan ini dirancang dengan menarik untuk memberi semangat dan memudahkan pemahaman dalam menerima materi. Pelatihan dilakukan dengan pemberian materi yang dibawakan oleh tim pengabdi melalui presentasi Power Point, dilanjutkan dengan forum group discussion. Selama kegiatan para Santri mengikuti dengan baik dan secara aktif melakukan diskusi (Gambar 4). 
ABDIMAS: Jurnal Pengabdian Masyarakat Universitas Merdeka Malang Volume 7, No 1, February 2022: 73-83
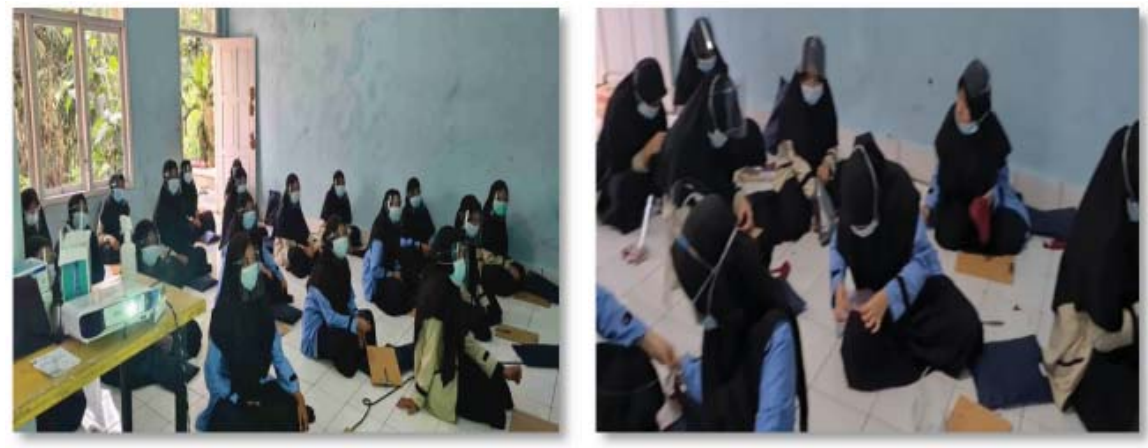

Gambar 4. Pemberian materi dan FGD

Setelah forum group discussion, santri melakukan demonstrasi penerapan protokol kesehatan. Di akhir kegiatan dilakukan pengisian kuesioner mengenai pengetahuan tentang COVID-19 untuk mengetahui pemahaman dan tingkat pengetahuan santri dalam mengikuti pelatihan.

Tabel 4. Tingkat pengetahuan santri

\begin{tabular}{lr}
\hline \multicolumn{1}{c}{ Tingkat Pengetahuan } & $\mathbf{N}=\mathbf{3 1}$ \\
\hline Baik $(>75 \%)$ & $11(35,48 \%)$ \\
Cukup $(50-75 \%)$ & $16(51,61 \%)$ \\
Kurang $(<50 \%)$ & $4(12,91 \%)$ \\
\hline
\end{tabular}

Berdasarkan Tabel 4, tingkat pengetahuan santri mengenai COVID-19 paling tinggi dengan kategori cukup sebesar 51,61\%. Secara keseluruhan pengetahuan santri dengan kategori cukup dan baik sebesar $87,09 \%$. Terdapat perbedaan tingkat pengetahuan yang cukup signifikan berdasarkan usia, jenis kelamin, dan jenjang pendidikan (Tabel 5).

Tabel 5. Tingkat pengetahuan berdasarkan usia, jenis kelamin, dan tingkat pendidikan

\begin{tabular}{|c|c|c|c|c|c|c|c|}
\hline \multirow[b]{2}{*}{$\begin{array}{c}\text { Tingkat } \\
\text { Pengetahuan }\end{array}$} & \multicolumn{2}{|c|}{ Usia } & \multicolumn{2}{|c|}{ Jenis Kelamin } & \multicolumn{3}{|c|}{ Pendidikan } \\
\hline & $\begin{array}{c}\leq 17 \\
(N=13) \\
n(\%)\end{array}$ & $\begin{array}{c}>17 \\
(N=18) \\
n(\%)\end{array}$ & $\begin{array}{c}\mathrm{L} \\
(\mathrm{N}=10) \mathrm{n} \\
(\%)\end{array}$ & $\begin{array}{c}P \\
(N=21) \\
n(\%)\end{array}$ & $\begin{array}{c}\text { Tsanawiyah } \\
(\mathrm{N}=2) \\
\text { n (\%) }\end{array}$ & $\begin{array}{c}\text { Aliyah } \\
(\mathrm{N}=22) \\
n(\%)\end{array}$ & $\begin{array}{c}\text { Lulus } \\
(\mathrm{N}=7), \\
\text { n (\%) }\end{array}$ \\
\hline Baik (>75) & $2(15,38)$ & $\begin{array}{r}9 \\
(50)\end{array}$ & $5(50)$ & $6(28,57)$ & $0(0)$ & $7(31,82)$ & $4(57,14)$ \\
\hline Cukup (50-75) & $9(69,24)$ & $7(38,89)$ & $4(40)$ & $12(57,14)$ & $1(50)$ & $12(54,55)$ & $3(42,86)$ \\
\hline Kurang $(<50)$ & $2(15,38)$ & $2(11,11)$ & $1(10)$ & $3(14,29)$ & $1(50)$ & $3(13,63)$ & $0 s(0)$ \\
\hline
\end{tabular}

Tingkat pengetahuan berdasarkan usia, kategori baik paling tinggi pada rentang usia $>17$ tahun. Tingkat pengetahuan berdasarkan jenis kelamin, kategori baik paling tinggi pada jenis kelamin lakilaki. Tingkat pengetahuan berdasarkan tingkat pendidikan, kategori baik paling tinggi pada jenjang pendidikan lulus sekolah (Tabel 5). 


\section{Pelatihan pembuatan handsanitizer}

Pelatihan pembuatan handsanitizer diikuti oleh trained troops santri laki-laki yang berjumlah 10 orang. Santri melihat demonstrasi yang dilakukan oleh seorang ahli farmasi, baik melalui video interaktif maupun secara langsung (Gambar 5). Kemudian menyiapkan alat dan bahan yang akan digunakan serta formula dan takarannya. Selanjutnya melakukan praktik pembuatan handsanitizer, dalam kesempatan ini mampu menghasilkan 10 botol handsanitizer ukuran $500 \mathrm{ml}$.
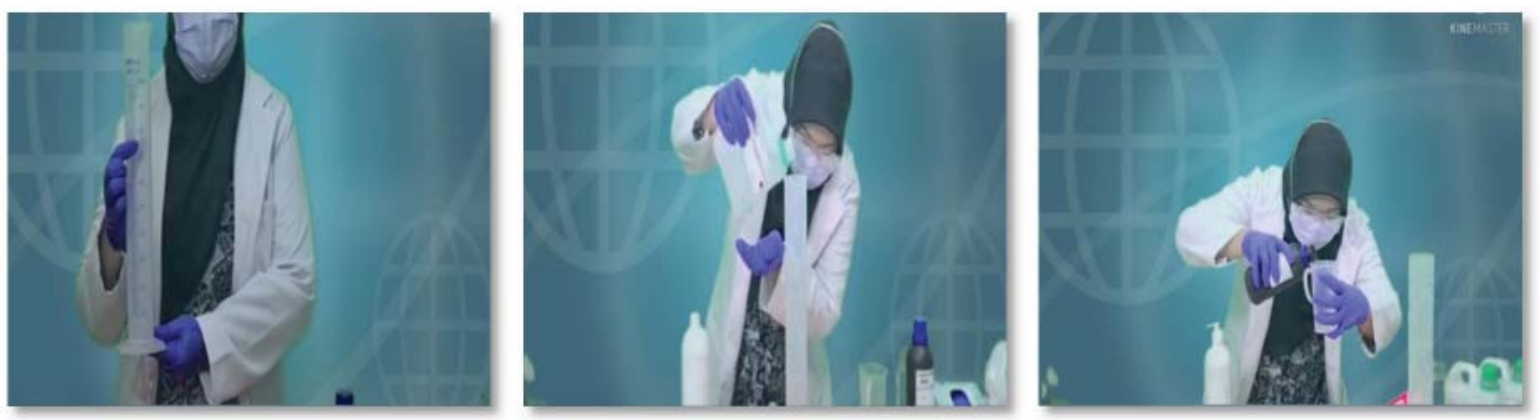

Gambar 5. Demonstrasi pembuatan handsanitizer

\section{Pelatihan pembuatan masker kain}

Pelatihan pembuatan masker kain diikuti oleh trained troops santri perempuan yang berjumlah 21 orang. Pertama, para santri melihat demonstrasi yang dibawakan oleh produsen pembuat masker kain (Gambar 6). Kedua, meyiapkan kit pembuatan masker kain secara berkelompok, yaitu dibagi menjadi 3 kelompok, masing-masing kelompok didampingi oleh tim pengabdi. Ketiga, masing-masing santri membuat masker kain berdasarkan pola yang telah diberikan. Pada kegiatan ini setiap santri berhasil menyelesaikan 1 masker kain dalam waktu 30 menit.
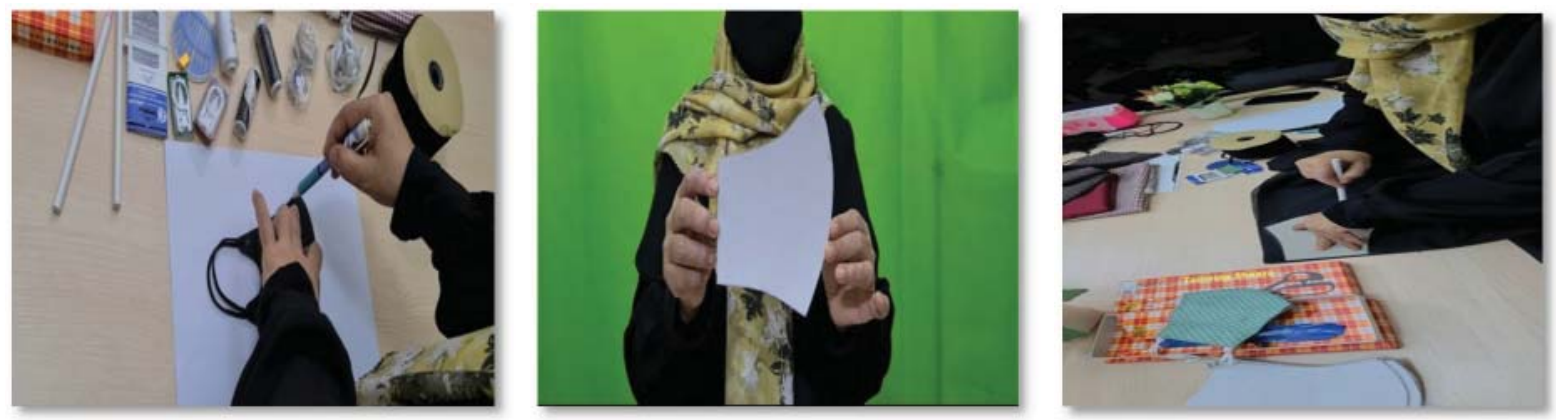

Gambar 6. Demonstrasi pembuatan masker kain

\section{Pelantikan trained troops santri}

Seluruh rangkaian kegiatan pengabdian berjalan dengan baik dan lancar. Kegiatan ini diikuti oleh seluruh trained troops santri dari awal kegiatan hingga akhir kegiatan. Di akhir kegiatan PKM ini dilakukan pelantikan trained troops santri sebanyak 31 orang (Gambar 7). Pelantikan ini sebagai simbol telah mengikuti rangkaian kegiatan trained troops santri yang akan menjadi kader pesantren menjadi tim pelaksana protokol kesehatan COVID-19 yang baik. 
ABDIMAS: Jurnal Pengabdian Masyarakat Universitas Merdeka Malang Volume 7, No 1, February 2022: 73-83
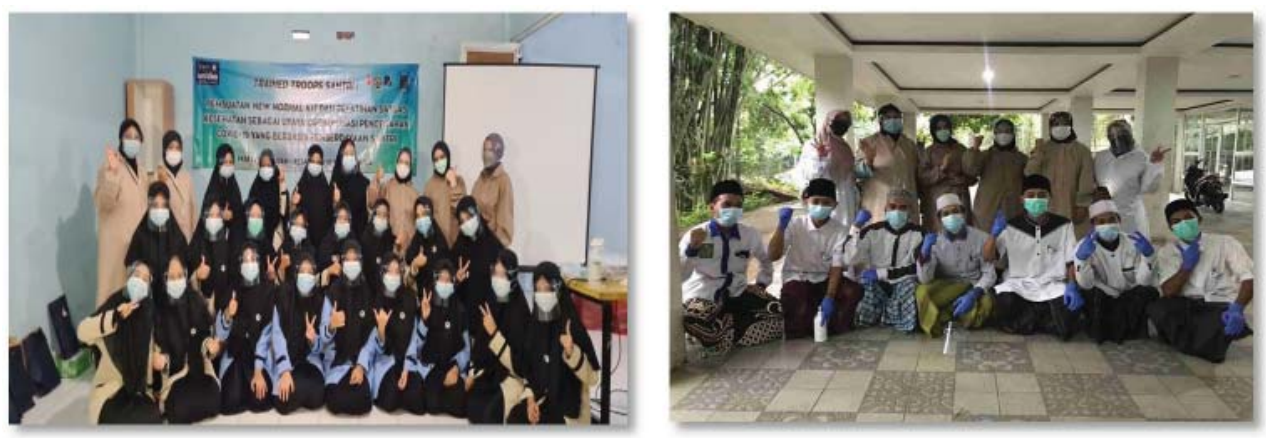

Gambar 7. Pelantikan trained troops santri

Berdasarkan data yang dirilis oleh pusat COVID Kota Bandung, grafik kasus baru terus meningkat. Lonjakan ini dihubungkan dengan masa liburan, di mana masyarakat lengah dan tidak semua patuh melaksanakan protokol kesehatan dan penerapan 5M. Pemberian informasi mengenai penerapan protokol kesehatan harus dilakukan secara masif baik di area publik maupun area terbatas. Pemberian materi berupa informasi mengenai COVID-19 efektif dalam memberikan pemahaman terhadap masyarakat. Pengabdian yang dilakukan pada kegiatan ini mampu memberikan pengetahuan yang cukup baik kepada santri mengenai COVID-19 khususnya mengenai penerapan protokol kesehatan yang benar. Berdasarkan kegiatan FGD masih banyak santri yang belum memahami tentang penerapan protokol kesehatan yang baik, bahkan beberapa belum mengetahui kondisi pandemi saat ini. Kegiatan pelatihan ini efektif dalam memberikan keilmuan khususnya mengenai COVID-19.

Pelatihan yang dilakukan pada kegiatan ini adalah pelatihan yang tepat dapat meningkatkan wawasan dan perilaku dalam pencegahan COVID-19 (Erlin et al., 2020). Pelatihan berupa pemberian materi serta pelatihan softskill mampu meningkatkan pengetahuan terhadap keilmuan (Usman et al., 2020). Pada kegiatan ini tingkat pengetahuan dengan kategori baik paling tinggi pada kelompok usia $>17$ tahun. Usia mempengaruhi tingkat pengetahuan karena semakin tinggi usia, semakin lama proses mendapatkan pengetahuan dan pengalaman. Jenis kelamin dipengaruhi oleh hormonal yang memengaruhi proses penerimaan ilmu pengetahuan, namun baik laki-laki maupun perempuan berdasarkan beberapa penelitian tidak mempengaruhi secara signifikan terhadap tingkat pengetahuan. Tingkat pendidikan mempengaruhi tingkat pengetahuan, semakin tinggi level pendidikan maka semakin banyak ilmu yang didapatkan. Tingkat pengetahuan dipengaruhi oleh banyak faktor, baik internal maupun eksternal. Faktor internal meliputi usia, jenis kelamin, tingkat pendidikan, kesehatan, daya konsentrasi, dll. Faktor eksternal meliputi lingkungan, sumber ilmu pengetahuan, fasilitas pendidikan, dll. (Wulandari et al., 2020). Kegiatan pendidikan dilakukan dengan memberikan penyuluhan berupa metode ceramah, diskusi, dan tanya jawab serta disampaikan melalui media poster efektif dalam memberikan edukasi kepada masyarakat mengenai COVID-19 (Caesaron et al., 2021; Choiriyah et al., 2021).

Pelatihan pembuatan handsanitizer cukup efektif dalam meningkatkan skill sehingga diharapkan dapat memproduksi handsanitizer mandiri dengan lebih efisien. Selain itu, kegiatan ini dapat meningkatkan pengetahuan mengenai pentingnya kebersihan tangan pada masa pandemi. Kebersihan tangan sangat penting karena dapat dengan mudah terkontaminasi dari kontak langsung dengan tetesan mikroorganisme di udara dari batuk dan bersin. Khususnya dalam situasi seperti wabah pandemi, sangat penting untuk memutus rantai penularan virus dengan praktik sanitasi tangan yang benar. Hal ini dapat dicapai dengan isolasi kontak dan alat pengendalian infeksi yang ketat seperti menjaga kebersihan tangan yang baik di lingkungan pesantren dan di tempat umum. Keberhasilan sanitasi tangan semata- 
mata tergantung pada penggunaan agen desinfektan tangan yang efektif yang diformulasikan dalam berbagai jenis dan bentuk seperti sabun antimikroba, pembersih tangan berbasis air atau alkohol, yang telah digunakan secara luas di masyarakat. Sampai saat ini, sebagian besar produk pembersih tangan yang efektif adalah formulasi berbasis alkohol yang mengandung 62\%-95\% alkohol karena dapat mendenaturasi protein mikroba dan kemampuan untuk menonaktifkan virus (Supriningrum et al., 2021; Jing et al., 2020).

Pelatihan pembuatan masker dapat memberikan skill yang mudah dipahami oleh santri. Pelatihan sehari ini telah menghasilkan santri yang terampil membuat masker kain. Penggunaan masker wajah, terutama untuk patogen dengan pembawa asimtomatik yang relatif umum, adalah strategi intervensi yang efektif. Namun, masker kain tidak sebaik masker medis sekali pakai, tetapi masih cukup efektif untuk penggunaan komunitas, contohnya di lingkungan pesantren, di mana tingkat paparan virus yang lebih rendah dibandingkan di tempat umum. Masker wajah dapat mengurangi total transmisi infeksi dan kematian, dan dapat menunda waktu puncak epidemi (Maclntyre \& Hasanain, 2020; Worby \& Chang, 2020).

Kegiatan pengabdian ini dapat berjalan lancar karena bantuan dari berbagai pihak. Pengurus Pesantren yang telah memfasilitasi ruangan dengan ventilasi dan sirkulasi udara yang baik dan pengkondisian santri yang tertib serta patuh dalam menggunakan perlengkapan protokol kesehatan dengan baik selama kegiatan. Selain itu, bantuan dari tim baik tim pengabdi dan juga tenaga ahli yang telah memaparkan prosedur kegiatan yang baik dan menarik sehingga mudah dipahami oleh santri.

\section{SIMPULAN DAN SARAN}

Pelatihan trained troops santri serta pelatihan softskill pembuatan new normal kit sangat berguna di masa pandemi karena akan meningkatkan pengetahuan penerapan protokol kesehatan dan kewaspadaan terhadap penularan COVID-19. Santri diharapkan lebih produktif dalam menghasilkan new normal kit secara mandiri, sehingga menciptakan lingkungan pesantren yang bersih, sehat, dan bebas COVID.

Kegiatan ini sebaiknya dilakukan secara berkala dan perlunya kegiatan monitoring terhadap terlaksananya penerapan protokol kesehatan di pesantren, khususnya pada masa pandemi.

\section{UCAPAN TERIMA KASIH}

Ucapan terima kasih kepada Keluarga Besar Pesantren Manarul Huda atas kerjasamanya, LPPM Unisba atas bantuan dana hibah PKM, dan semua pihak yang telah memberikan dukungan dan partisipasi dalam kegiatan PKM ini.

\section{DAFTAR PUSTAKA}

Caesaron, D., Salma, S. A., Prasetio, M. D., \& Rifai, M. H. (2021). Edukasi dan sosialisasi pencegahan dan pengendalian COVID-19 melalui media poster di Desa Bojongsoang, Kabupaten Bandung. Abdimas: Jurnal Pengabdian Masyarakat Universitas Merdeka Malang, 6(2), 221-229. https:// doi.org/10.26905/abdimas.v6i2.5354

Choiriyah, N. A., Devi, I. M. R., Sanjaya, S. A., Dewi, I. C., \& Rahmah, L. (2021). Penyuluhan pencegahan penularan COVID-19 di lingkungan kantor dan pembuatan lemongrass coolant melalui Live Zoom. Abdimas: Jurnal Pengabdian Masyarakat Universitas Merdeka Malang, 6(1), 18-26. https://doi.org/10.26905/abdimas.v6i1.4865 
ABDIMAS: Jurnal Pengabdian Masyarakat Universitas Merdeka Malang

Volume 7, No 1, February 2022: 73-83

Dharmaraj, S., Ashokkumar, V., Hariharan, S., Manibharathi, A., Show, P. L., Chong, C. T., \& Ngamcharussrivichai, C. (2021). The COVID-19 pandemic face mask waste: A blooming threat to the marine environment. Chemosphere, 272, 129601.

https://doi.org/10.1016/j.chemosphere.2021.129601

Erlin, F., Putra, I. D., \& Hendra, D. (2020). Peningkatan pengetahuan siswa dalam pencegahan penularan COVID-19. JMM: Jurnal Masyarakat Mandiri, 4(4), 663-669.

https://doi.org/10.31764/jmm.v4i4.2652

Gibbons, D. W., Sandbrook, C., Sutherland, W. J., Akter, R., Bradbury, R., Broad, S.,... \& Ockendon, N. (2021). The relative importance of COVID-19 pandemic impacts on biodiversity conservation globally. Conservation Biology. https://doi.org/10.1111/cobi.13781

Gold, N. A., Mirza, T. M., \& Avva, U. (2020). Alcohol sanitizer. StatPearls Publishing.

Jing, J. L. J., Pei Yi, T., Bose, R. J. C., McCarthy, J. R., Tharmalingam, N., \& Madheswaran, T. (2020). Hand sanitizers: A review on formulation aspects, adverse effects, and regulations. International Journal of Environmental Research and Public Health, 17(9), 3326. https://doi.org/10.3390/ijerph17093326

Khoiroh, R. K., \& Fachrunisa, R. A. (2020). Pesantren dan COVID-19. Ragam Ulas Kebencanaan, 69.

MacIntyre, C. R., \& Hasanain, S. J. (2020). Community universal face mask use during the COVID 19 pandemic from households to travellers and public spaces. Journal of Travel Medicine, 27(3). https://doi.org/10.1093/jtm/taaa056

Parasher, A. (2021). COVID-19: Current understanding of its pathophysiology, clinical presentation and treatment. Postgraduate Medical Journal, 97(1147), 312-320. http://dx.doi.org/10.1136/postgradmedj-2020-138577

Pinals, D. A., Hepburn, B., Parks, J., \& Stephenson, A. H. (2020). The behavioral health system and its response to COVID-19: A snapshot perspective. Psychiatric Services, 71(10), 1070-1074. https://doi.org/10.1176/appi.ps.202000264

Sebong, P. H., Tjitradinata, C., \& Goldman, R. E. (2021). Promoting COVID-19 prevention strategies in student dormitory setting: A qualitative study. Journal of American College Health, 1-10. https://doi.org/10.1080/07448481.2021.1926271

Shereen, M. A., Khan, S., Kazmi, A., Bashir, N., \& Siddique, R. (2020). COVID-19 infection: Origin, transmission, and characteristics of human coronaviruses. Journal of Advanced Research, 24, 91-98. https://doi.org/10.1016/j.jare.2020.03.005.

Shirani, K., Sheikhbahaei, E., Torkpour, Z., Nejad, M. G., Moghadas, B. K., Ghasemi, M.,... \& Khandan, A. (2020). A narrative review of COVID-19: the new pandemic disease. Iranian Journal of Medical Sciences, 45(4), 233. https://doi.org/10.30476/ijms.2020.85869.1549

Sufiyanto, S., Yuniarti, S., \& Andrijono, D. (2020). Sosialisasi dan edukasi penilaian mandiri terhadap risiko penularan COVID-19 melalui InaRISK Personal. Abdimas: Jurnal Pengabdian Masyarakat Universitas Merdeka Malang, 5(3), 209-219. https://doi.org/10.26905/abdimas.v5i3.5004

Supriningrum, R., Sa'adah, H., \& Helmidanora, R. (2021). Pelatihan pembuatan hand sanitizer di Kantor Dinas Perindustrian Kota Samarinda. Jurnal Abdimas Mahakam, 5(01), 119-124. https://doi.org/10.24903/jam.v5i01.1103

Syam, N., Gafur, A., \& Hamzah, W. (2018). PkM Pengembangan pos kesehatan pesantren (poskestren) di Yayasan Wakaf Umi Pesantren Wihdatul Ulum Desa Bontokassi, Kec. Parangloe, Kab. Gowa Tahun 2017. Jurnal Balireso: Jurnal Pengabdian pada Masyarakat, 3(1). 


\section{Santri trained troops: Making new normal kits and training for the COVID-19 task force}

Meta Maulida Damayanti, Yuniarti Yuniarti, Meike Rachmawati, Mia Kusmiati

Tosepu, R., Effendy, D. S., \& Ahmad, L. O. A. I. (2020). The first confirmed cases of COVID-19 in Indonesian citizens. Public Health of Indonesia, 6(2), 70-71.

https://dx.doi.org/10.36685/phi.v6i2.337

Usman, U., Budi, S., \& Sari, D. N. A. (2020). Pengetahuan dan sikap mahasiswa kesehatan tentang pencegahan COVID-19 di Indonesia. Jurnal Ilmu Keperawatan dan Kebidanan, 11(2), 258-264. http://dx.doi.org/10.26751/jikk.v11i2.835

Velavan, T. P., \& Meyer, C. G. (2020). The COVID 19 epidemic. Tropical medicine \& international health, 25(3), 278.

Worby, C. J., \& Chang, H. H. (2020). Face mask use in the general population and optimal resource allocation during the COVID-19 pandemic. Nature Communications, 11(1), 4049.

https://doi.org/10.1038/s41467-020-17922-x

Wulandari, A., Rahman, F., Pujianti, N., Sari, A. R., Laily, N., Anggraini, L., Azmiyannoor, M. (2020). Hubungan karakteristik individu dengan pengetahuan tentang pencegahan Coronavirus Disease 2019 pada masyarakat di Kalimantan Selatan. Jurnal Kesehatan Masyarakat Indonesia, 15(1), 42-46. https://doi.org/10.26714/jkmi.15.1.2020.42-46

Yusuf, Y. (2020, Desember 3). Ahli epidemiologi: Sembari menunggu vaksin, masyarakat harus disiplin terapkan prokes 3M. Portal Kominfo. 